\title{
HARMONISASI DAN SINKRONISASI PERATURAN HUKUM PERKOPERASIAN DAN LEMBAGA KEUANGAN MIKRO
}

\author{
Muhammad Muhtarom \\ Universias Muhamadiyah Surakarta \\ Mahasiswa Program doktor IImu Hukum Universitas Sebelas Maret (UNS) \\ e-mail : mmmuhtarom@gmail.com
}

\begin{abstract}
The presence of Act No. 1 of 2013 on Micro Finance Institutions, have given rise to legal problems for financial enterprises of Cooperative, because cooperatives engaged in financial services governed by two kinds of regulation, namely cooperative legislation and regulation of microfinance institutions (MFIs). Dualism of laws has given rise to overlapping regulation, supervision and oversight by the relevant agencies, as well as the contradictions settings between one to another. The legal problems required solutions through harmonization and synchronization of laws pertaining to the MFI Cooperative.
\end{abstract}

Keywords: Synchronization, Cooperatives, the Finance Institution Micro

\begin{abstract}
Abstrak
Kehadiran Undang Undang Nomor 1 Tahun 2013 tentang Lembaga Keuangan Mikro, telah memunculkan problem hukum bagi badan usaha Koperasi, karena Koperasi yang bergerak di bidang jasa keuangan diatur oleh dua macam regulasi, yaitu peraturan perundangan perkoperasian dan peraturan Lembaga Keuangan Mikro (LKM). Adanya dualisme peraturan hukum ini telah menimbulkan tumpang-tindih pengaturan, pengawasan dan pembinaan oleh instansi terkait, serta adanya kontradiksi-kontradiksi pengaturannya di antara satu dengan lainnya. Problem hukum itu memerlukan pemecahannya melalui harmonisasi dan sinkronisasi peraturan perundangan yang berkaitan dengan LKM Koperasi.
\end{abstract}

Kata Kunci: Sinkronisasi, Perkoperasian, Lembaga Keungan Mikro

\section{A. Pendahuluan}

Hukum merupakan karya manusia yang mengkonstruksi nilai-nilai yang ada dalam masyarakat. Sebagai sebuah proses konstruksi, keberadannya tidak lepas dari berbagai peristiwa atau kenyataan sosial yang tidak berdiri sendiri, akan tetapi saling berhubungan satu sama lain. Satjipto Rahardjo mengemukakan bahwa hukum merupakan pencerminan dari kehendak manusia tentang bagaimana seharusnya masyarakat itu dibina dan kemana harus diarahkan. oleh karenanya hukum mengandung rekaman dari ide-ide yang dipilih oleh masyarakat setempat terutama ide mengenai keadilan (Satjipto, 1996: 18)

Seiring dengan perkembangan hukum untuk mengakomodasi kepentingan negara modern, masyarakat juga menginginkan fungsi hukum yang dapat menjamin kepastian dan kegunaan dalam hubungan mereka satu sama lain. Dengan demikian maka nilai dasar dari hukum adalah sebagaimana telah diintrodusir oleh
Gustav Radbruch, yaitu keadilan, kegunaan dan kepastian (Barda Nawawi, 2003: 54)

Substansi hukum yang bagaimanakah yang secara konkrit dipandang adil dan tidak adil? dan bagaimanakah cara atau prosedur untuk menegakkan nilai keadilan, agar hukum benarbenar terwujud secara nyata dan dapat dirasakan manfaatnya bagi manusia? Hal ini memerlukan bentuk rumusan normatif yang konkrit agar mengandung kepastian, sehingga dapat dijadikan pedoman perilaku yang predicable bagi semua anggota masyarakat.

Salah satu persoalan yang saat ini sedang dihadapi masyarakat menyangkut keadilan, kemanfaatan dan kepastian hukum adalah persoalan di bidang hukum lembaga keuangan, khususnya lembaga keuangan mikro Koperasi. Persoalan hukum tentang LKM di Indonesia sebenarnya telah lama berlangsung akan tetapi sampai saat ini belum dapat teratasi secara memadahi. Problem hukum LKM Koperasi seperti itu memamng merupakan problum umum perihal lembaga keuangan mikro (mocro finance/ MFi) 
yang banyak dijumpai juga di negara-negara lain (Patrick Meagher. 2002).

Problem hukum yang dihadapi oleh LKM awalnya berakar dari masalah legalitas untuk melakukan kegiatan penghimpunan dana simpanan masyarakat. Kegiatan penghimpunan dana simpanan/ tabungan merupakan usaha penggalian dana dari masyarakat yang sangat penting bagi LKM untuk menjalankan usaha intermediasi keuangan (simpan-pinjam). Namun, kegiatan penghimpunan simpanan dana yang dilakukan LKM menghadapi kendala hukum karena adanya ketentuan dalam Pasal 16 ayat (1) Undang-Undang Nomor 7 Tahun 1992 tentang Perbankan sebagaimana telah diubah dengan Undang-Undang Nomor 10 Tahun 1998 tentang Perubahan Undang Undang Perbankan yang menentukan bahwa lembaga keuangan selain bank dilarang menghimpunan dana simpanan masyarakat, kecuali ada undang undang tersendiri yang mengaturnya.

Proses pembentukan undang undang khusus untuk melegalisasi usaha LKM itu berlangsung demikian alot dan berlarut. Barulah kemudian pada tahun 2013 undang undang khusus itu berhasil diwujudkan, yaitu dengan disahkannya Undang Undang Nomor 1 Tahun 2013 tentang Lembaga Keuangan Mikro.

Lahirnya Undang Undang Nomor 1 Tahun 2013 adalah sebuah langkah kemajuan bagi keberadaan LKM dan diharapkan akan dapat mengatasi masalah ketidak-pastian hukum LKM dan dapat memberikan legalitas kegiatan penghimpunan dana simpanan dari masyarakat. Namun, ternyata lahirnya Undang Undang ini telah berimplikasi pada terjadinya pengaturan secara ganda bagi Koperasi. Sebab Koperasi menjadi berada di bawah pengaturan oleh Undang Undang Nomor 25 Tahun 1992 tentang Perkoperasian dan Undang Undang Nomor 1 Tahun 2013 tentang Lembaga Keuangan Mikro. Berlakunya dualisme hukum bagi LKM Koperasi itu menuntut adanya keharmonisan antara kedua macam peraturan hukum, agar LKM Koperasi dapat mematuhi kedua-duanya tanpa dihadapkan masalah inkonsistensi yang menyebabkan adanya ketidak-pastian hukum.

Berdasarkan hal itu maka setelah lahirnya undang Undang Nomor 1 Tahun 2013 tentang LKM, maka bagaimanakah keharmonian peraturan hukum yang mengatur tentang LKM Koperasi? Apa kelemahaman hukum yang terdapat di dalam kedua macam peraturan perundangan tersebut, dan bagaimanakah solusi pemecahannya?
Tulisan ini bermaksud hendak menyajikan hasil penelitian terkait dengan problem dualisme hukum yang terjadi dalam pengaturan LKM Koperasi tersebut, beserta alternatif pemecahannya.

\section{B. Metode Penelitian}

Penelitian ini merupakan penelitian doktriner atau penelitian dogmatis untuk mencari taraf sikronisasi hukum (Soerjono Soekanto, 1986: 51). Melalui studi pustaka (library research) terhadap berbagai dokumen dan literatur hukum yang terkait, data diolah dan dilakukan analisis secara kualititaif. Data penelitian ini diperoleh dari data sekunder yaitu data yang diambil dari bahan pustaka, meliputi antara lain buku buku hukum, literatur, peraturan perundang undangan, dokumen resmi, hasil penelitian terdahulu, artikel, majalah, surat kabar, dan sumber lainnya yang berkaitan dengan penelitian ini. Data sekunder tersebut bersumber dari bahan hukum primer yang berupa peraturan perundang-undangan yang berkaitan dengan perbankan, perkoperasian, dan lembaga keuangan mikro.

\section{Hasil Penelitian dan Pembahasan}

\section{Disharmoni Peraturan Hukum tentang} LKM Koperasi

Menurut ketentuan Pasal 5 ayat (1) Undang Undang Nomor 1 Tahun 2013 tentang Lembaga Keuangan Mikro, setiap LKM yang menjalankan usahanya wajib memiliki badan hukum yang harus dipilih, yaitu antara badan hukum Koperasi atau badan hukum Perseroan Terbatas (PT). Berdasarkan ketentuan tersebut berarti secara yuridis LKM yang berbadan hukum Koperasi dengan sendirinya akan berada di bawah pengaturan 2 macam perundang-undangan secara bersamaan, yaitu: (1) Undang Undang Nomor 25 Tahun 1992 tentang Perkoperasian beserta peraturan pelaksanaannya dan (2) Undang Undang Nomor 1 Tahun 2013 tentang Lembaga Keuangan Mikro beserta peraturan pelaksanaannya.

LKM Koperasi atau badan usaha Koperasi yang khusus menjalankan usaha keuangan, terdiri dari Koperasi Simpan Pinjam (KSP), Unit Simpan Pinjam (USP), Koperasi Jasa Keuangan Syariah (KJKS), dan Unit Jasa Keuangan Syariah (UJKS). Koperasi secara umum diatur di dalam Undang Undang Nomor 25 Tahun 1992 tentang Perkoperasian. KSP dan USP diatur di dalam Peraturan Pemerintah Nomor 9 
Tahun 1995 tentang Pelaksanaan kegiatan Simpan Pinjam oleh Koperasi. Sedangkan Koperasi/ Unit Jasa Keuangan Syariah diatur dengan Keputusan Menteri Negara Koperasi dan UKM Nomor: 91/Kep/M.KUKM/IX/2004 tanggal 2 September 2004.

Ketentuan hukum dari Pasal 5 ayat (1) tersebut telah menyebabkan terjadinya pengaturan ganda bagi LKM Koperasi. Dualisme pengaturan hukum itu berimplikasi pada terjadinya tumpang-tindih kewenangan antar instansi yang mengatur, inkonsistensi, dan kontradiksi-kontradiksi dalam pengaturan, pengawasan dan pembinaan terhadap LKM Koperasi.

Undang Undang Nomor 1 Tahun 2013 tentang Lembaga Keuangan Mikro mengatur secara umum untuk semua jenis LKM, baik skala kecil maupun skala besar, mengatur secara ketat disertai dengan berbagai bentuk ancaman sanksi. Model pengaturan yang diterapkan adalah dengan menggunakan pengaturan yang berasas kehati-hatian perbankan (prudential banking principles). LKM Koperasi diatur oleh Undang undang ini dengan pengaturan dan pengawasan yang dikendalikan oleh otoritas Jasa Keuangan (oJK), yang diberlakukan kepada semua LKM.

cara pengaturan dalam Undang Undang Nomor 1 Tahun 2013 itu sangat bertolakbelakang dengan cara pengaturan dalam peraturan perundangan perkoperasian yang berprinsip memberikan, otonomi, kemandirian, dan kelonggaran bagi LKM Koperasi. Hal itu telah menimbulkan persoalan hukum baru bagi LKM Koperasi.

Adanya tumpang-tindih tentang pembinaan, pengaturan dan pengawasan LKM Koperasi dapat dilihat dari ketentuanketentuan yang terdapat pada kedua macam peraturan perundangan. Menurut Penjelasan Umum Undang Undang Nomor 25 tahun 1992 tentang Perkoperasian, pembinaan terhadap Koperasi dilaksanakan oleh Kementerian Koperasi (Penjelasan Umum UU No.25 Tahun 1992)

Sedangkan menurut Pasal 28 ayat (1) Undang Undang Nomor 1 Tahun 2013 tentang Lembaga Keuangan Mikro, kegiatan pembinaan, pengaturan dan pengawasan terhadap LKM (termasuk Koperasi) adalah di bawah wewenang otoritas Jasa Keuangan (oJK). Adapun bunyi Pasal 28 ayat (1) tersebut adalah sebagai berikut: "Pembinaan, pengaturan, dan pengawasan LKM dilakukan oleh otoritas Jasa Keuangan."
Berdasarkan kedua aturan tersebut timbul pertanyaan siapakah yang berwenang untuk melakukan pengautran dan pembinaan terhadap LKM Koperasi? Apakah kementerian Koperasi ataukah otoritas Jasa keuangan?

Dualisme peraturan perundangan yang berlaku bagi LKM Koperasi juga menimbulkan inkonsistensi pengaturan. Menurut peraturan perundangan perkoperasian, LKM Koperasi menjalankan usaha dengan prinsip kemandirian. Pengertian kemandirian Koperasi yaitu dapat berdiri sendiri dan tidak tergantung pada pihak lain, percaya pada kemampuan sendiri, otonom, swadaya, mengelola sendiri, serta berani mempertanggung-jawabkan perbuatannya sendiri. Berdasarkan prinsip koperasi itu Pemerintah bertugas memperkuat dan ikut menjaga terpeliharanya prinsip kemandirian Koperasi. Hal ini diperjelas oleh Undang Undang Perkoperasian bahwa untuk melaksanakan peranannya dalam menetapkan kebijaksanaan pembinaan Pemerintah perlu mendorong pertumbuhan, perkembangan, dan pemasyarakatan Koperasi. Sesuai dengan prinsip kemandirian, pembinaan tersebut dilaksanakan tanpa mencampuri urusan internal organisasi Koperasi.

Prinsip kemandirian Koperasi itu telah memberikan otonomi kepada Koperasi, sehingga kegiatan pengaturan dan pengawasan di dalam LKM Koperasi merupakan urusan internal organisasi yang diatur dan diawasi sendiri melalui organ Pengurus dan Pengawas Koperasi sendiri. Sedangkan cara pengaturan, pengawasan dan pembinaan LKM menurut Undang Undang Nomor 1 Tahun 2013 tentang Lembaga Keuangan Mikro, semua LKM diperlakukan secara sama, tanpa membedakan skala usaha kecil dan besar, Semua LKM diatur dan diawasi oleh oJK secara prudent layaknya lembaga keuangan bank. cara pengaturan yang demikian tidak selaras dengan pengaturan dalam peraturan perundangan perkoperasian, yang nersifat mendidik, meemberdayakan dan memberikan kelonggaran. cara pengaturan yang prudent akan sangat membatasi ruang gerak dan pertumbuhan LKM, terutama LKM Koperasi yang lazim dimulai dari skala kecil atau yang melalui tahap perintisan kegiatan kewirausahaan mikro.

Dualisme pengaturan bagi LKM Koperasi akan menyulitkan LKM Koperasi menentukan aturan hukum mana yang harus dipatuhi. 
Padahal terdapat beberapa perbedaan kontradiktif antara pengaturan dari peraturan hukum perkoperasian dengan peraturan LKM, diantaranya pengaturan mengenai: (1) syarat pendirian, (2) ijin usaha, (3) syarat pemodalan, (4) lingkup kegiatan usaha, (5) kewajiban membuat laporan, (6) pengawasan,
(7) pengumuman laporan keuangan, dan (8) ancaman sanksi.

Undang Undang Nomor 1 Tahun 2013 tentang Lembaga Keuangan Mikro telah membuat pengaturan tentang kelembagaan dan tata-kelola LKM secara umum dapat dilihat pada Tabel, sebagai berikut:

\section{Tabel}

\section{POKOK POKOK PENGATURAN LKM KOPERASI BERdASARKAN UNdANG UNdANG NOMOR 1 Tahun 2013}

\begin{tabular}{|c|c|c|}
\hline ASPEK & SUBSTANSI HUKUM & PASAL \\
\hline \multirow[t]{7}{*}{$\begin{array}{l}\text { Aspek } \\
\text { Kelembagaan }\end{array}$} & $\begin{array}{l}\text { Semua LKM Koperasi, baik besar atau kecil, tanpa } \\
\text { kecuali, berada di bawah pengaturan, pengawasan dan } \\
\text { pembinaan OJK }\end{array}$ & Pasal 28 ayat (1) \\
\hline & $\begin{array}{l}\text { Semua LKM Koperasi, baik besar atau kecil, tanpa kecuali, } \\
\text { dilarang menjalankan kegiatan usahanya, tanpa memiliki } \\
\text { ijin dari OJK. (Jadi mulai Januari 2015, LKM Koperasi kecil } \\
\text { yang tidak memiliki ijin dari oJK akan berstatus sebagai } \\
\text { LKM Koperasi ilegal dan terancam sanski pidana) }\end{array}$ & $\begin{array}{l}\text { Pasal } 9 \text { dan Pasal } \\
34 \text { ayat (1) }\end{array}$ \\
\hline & Semua LKM Koperasi wajib berbadan hukum & Pasal 4 dan Pasal 5 \\
\hline & $\begin{array}{l}\text { Untuk mendirikan LKM Koperasi harus memenuhi syarat } \\
\text { pemodalan minimal }\end{array}$ & Pasal 4 huru (a) \\
\hline & $\begin{array}{l}\text { Semua LKM Koperasi, baik besar atau kecil, belum } \\
\text { mendapat pengaturan yang jelas dan tegas tentang } \\
\text { legalitasnya menghimpun dana simpanan (PDSM) dari } \\
\text { non-anggota koperasi. }\end{array}$ & Pasal 11 \\
\hline & $\begin{array}{l}\text { Bagi semua LKM Koperasi yang tidak mematuhi ketentuan } \\
\text { tersebut akan dikenakan sanksi pidana. }\end{array}$ & $\begin{array}{l}\text { Pasal } 33 \text { dan Pasal } \\
34\end{array}$ \\
\hline & $\begin{array}{l}\text { Mulai bulan Januari tahun } 2015 \text {, semua LKM kecil yang } \\
\text { tidak memenuhi ketentuan di atas, meskipun sekarang } \\
\text { masih berjalan dengan baik, dengan sendirinya menjadi } \\
\text { LKM informal dan ilegal. }\end{array}$ & Pasal 42 \\
\hline \multirow[t]{7}{*}{$\begin{array}{l}\text { Aspek } \\
\text { Pengelolaan }\end{array}$} & $\begin{array}{l}\text { LKM Koperasi, besar atau kecil, wajib membuat pencatatan } \\
\text { dan pembukuan sesuai standar akuntansi }\end{array}$ & Pasal 29 \\
\hline & $\begin{array}{l}\text { LKM Koperasi, besar atau kecil, harus membuat laporan } \\
4 \text { bulanan ke OJK, dan mengumumkan laporan keuangan }\end{array}$ & Pasal 30 \\
\hline & $\begin{array}{l}\text { LKM Koperasi tidak dapat menentukan suku bunga } \\
\text { pinjaman sendiri tapi diatur dan diawasi oleh oJK }\end{array}$ & Pasal 11 ayat (2) \\
\hline & $\begin{array}{l}\text { Wilayah usaha Koperasi ditentukan dan dibatasi pada } \\
\text { lingkup wilayah tertentu }\end{array}$ & Pasal 16 \\
\hline & $\begin{array}{l}\text { Kegiatan LKM koperasi, baik kecil atau besar, mendapat } \\
\text { pemeriksaan dan pengawasan dari OJK }\end{array}$ & Pasal 31 \\
\hline & $\begin{array}{l}\text { LKM Koperasi yang kesulitan likuiditas dan solvabilitas } \\
\text { akan diambil tindakan-tindakan oleh oJK, sampai } \\
\text { kemungkinan dilakukan pencabutan ijin usaha }\end{array}$ & Pasal 23 \\
\hline & $\begin{array}{l}\text { Semua tata kelola keuangan LKM Koperasi tersebut } \\
\text { berada di bawah pengaturan dan pengendalian oJK dan } \\
\text { yang melanggar dikenakan sanksi-sanksi }\end{array}$ & $\begin{array}{l}\text { Pasal } 28 \text { ayat }(1) \\
\text { Pasal } 33 \text {, Pasal } 35- \\
38\end{array}$ \\
\hline
\end{tabular}


Pengaturan terhadap LKM yang berbadan hukum Koperasi seperti yang diatur di dalam Undang Undang Nomor 1 Tahun 2013 tentang Lembaga Keuanagn Mikro tersebut berarti memaksakan semua LKM Koperasi wajib menjalankan usahanya layaknya lembaga perbankan (mikro) yang bersifat prudent. Mengapa diatur secara demikian, dan jika itu berlaku juga untuk LKM Koperasi kecil maka bagaimanakah masa depan nasib Koperasi kecil yang tersebar seantero wilayah Indonesia? Apakah pengaturan yang demikian mengandung nilai keadilan, kemanfaatan dan keefektifan hukum?

Berkenaan dengan cara pendirian badan hukum Koperasi sudah terdapat aturannya secara jelas di dalam peraturan perundangan perkoperasian, yaitu dengan cara pembuatan Akta Pendirian Koperasi yang disahkan oleh Pemerintah. Jika Akta Pendirian itu sudah disahkan, maka dengan sendirinya akta itu berlaku sebagai ijin usaha, sehingga koperasi tidak perlu lagi mengajukan ijin usaha. Akan tetapi di dalam Undang Undang Nomor 1 Tahun 2013 tentang Lembaga Keuangan Mikro hal itu diatur secara berbeda karena LKM Kopersi harus mengajukan ijin usahanya ke otoritas Jasa Keuangan. Perbedaanperbedaan pengaturan dari kedua Undang Undang tersebut merupakan pengaturan yang bersifat tumpang-tindih (ovelapp) yang menyebabkan ketidak-pastian hukum bagi LKM Koperasi.

Tumpang tindih kewenangan terjadi antara Kementerian Koperasi dan Usaha Kecil dan Menengah, dengan wewenang otoritas Jasa Keuangan (OJK). Padahal antara kedua instansi menggunakan cara pengaturan, pengawasan dan pembinaan yang sangat berbeda dan bertolak-belakang. Dualisme pengaturan juga mengakibatkan inkonsistensi dalam mengatur terhadap LKM Koperasi, sebab di satu sisi LKM Koperasi dikembangkan dengan prinsip kemandirian yang bersifat mengatur-diri dan mengawasidiri, di sisi lain diberikan regulasi secara berlawanan, yaitu dengan pengaturan berasas kehati-hatian (prudential regulation) dan diawasi oleh oJK dengan disertai ancaman sanksi-sanksi. Inkonsistensi pengaturan itu berimplikasi pada ketidak-selarasan dan kontradiksi norma-norma antara regulasi dalam perkoperasian dengan regulasi dalam LKM. Kontradiksi norma-norma itu ditemukan pada; Pertama, adanya larangan untuk menjalankan usaha bagi semua
LKM, baik skala kecil atau besar, jika tanpa mendapat ijin dan terpenuhinya persyaratan dari OJK, adalah sebuah ketentuan yang berlawanan dengan sistem kewirausahaan dan kemandirian usaha masyarakat mikro dalam kegiatan Koperasi. Sebab kegiatan Koperasi dapat dimulai dari bentuk kelompok usaha yang sederhana sejak sebelum berbadan hukum (pra koperasi). Kedua, regulasi dalam LKM yang berlaku bagi semua LKM tanpa pembedaan skala kecil dan besar, yang mewajibkan persyaratan pemodalan minimal adalah suatu bentuk pemaksaan kepada LKM Koperasi kecil untuk harus memulai usahanya dari skala modal tertentu. Pemaksaan (kewajiban) yang demikian tidak selaras dengan tujuan Pemerintah untuk menumbuh-kembangkan kewirausahaan masyarakat mikro yang dibina dari skala kecil sesuai dengan kapasitas dan kemampuan modal lembaga mikro yang bersangkutan. Ketiga, regulasi dalam LKM yang diberlakukan kepada semua LKM tanpa pembedaan skala kecil dan besar yang semuanya diatur secara prudent adalah suatu bentuk pemaksaan kepada LKM Koperasi kecil untuk wajib berpola kerja formalprofesional layaknya usaha perbankan. Pengaturan yang demikian bertentangan dengan regulasi dalam perkoperasian yang memperkuat kemandirian LKM Koperasi dan memberi kelonggaran serta kemudahan. Keempat, ketentuan ancaman sanksi-sanksi admnitratif dan pidana yang diberlakukan untuk semua LKM Koperasi, adalah sangat bertolak-belakang dengan norma-norma tentang pembinaan, pemberdayaan, perlindungan dan pengayoman terhadap Koperasi, terutama bagi LKM Koperasi kecil. Kelima, regulasi dalam perkoperasian yang memberikan otonomi dan kemandirian bagi semua LKM Koperasi, skala kecil maupun besar, tanpa pembatasan kemandirian dan otonomi sampai batas-batas skala tertentu, akan menumbuhkan suatu LKM Koperasi yang berkapasitas bank tetapi berada di luar pengaturan dan pengawasan OJK. Hal ini bertentangan dengan tujuan dari regulasi LKM.

Jika Undang Undang Nomor 1 Tahun 2013 tentang Lembaga Keuangan Mikro ini bertujuan hendak mengatur secara komprehensif, memberikan kepastian hukum, dan memenuhi kebutuhan layanan jasa keuangan mikro, maka substansi hukum yang terkandung dalam undang undang 
itu secara normatif maupun praktis masih belum sinkron dan dengan norma-norma yang diatur dalam peraturan perundangan perkoperasian, serta belum harmonis dengan kebutuhan atau kondisi riil masyarakat mikro. Padahal berdasarkan pengalaman sebelumnya sebagaimana hasil penelitian yang dilakukan oleh Sumantoro Martowijoyo, penggunaan kerangka hukum prudential yang demikian bukanlah suatu cara pengaturan yang efektif dalam memberdayakan LKM dan tidak sesuai dengan karakteristik LKM yang mandiri dan otonom (Sumantoro, 2001: 455), apalagi bagi LKM yang berskala kecil atau masih tahap perintisan. Berdasarkan hasil penelitiannya, Sumantoro menyatakan bahwa pelaksanaan UU Perbankan No. 7/1992 yang mewajibkan Lembaga Kredit Pedesaan (LKP) mengadaptasi sistem BPR, penerapan penilaian tingkat kesehatan berdasarkan kriteria cAMEL (capital adequacy, assets quality, management, earnings, liquidity), kewajiban pelaporan bulanan beserta peraturan-peraturan pelaksanaan, berdampak negatif terhadap kinerja dan kelestarian LKP, karena membawa implikasi perubahan budaya kinerja, perubahan sistem akuntansi, struktur organisasi, dan peningkatan biaya yang sukar diadaptasi oleh sebagian besar LKP. Apabila sistem BPR akan diterapkan sepenuhnya pada BKD, maka diperkirakan 90\% dari seluruh BKD akan mengalami marjin yang negative (Sumantoro, 2001: 456)

Keadaan lembaga-lembaga keuangan mikro pada kenyataannya lebih cocok dengan hukum yang bersifat mendidik, membina, dan melindungi seperti model pengaturan yang diterapkan dalam hukum perkoperasian.

Di sinilah letak permasalah hukum yang mengatur tentang LKM Koperasi, sehingga diperlukan adanya kerangka pengaturan dan pendekatan yang lebih komprehensif sebelum menyusun langkah singkronisasi peraturan perundang-undangannya. Terjadinya kesalahan dalam pendekatan dan pengaturan akan memicu terjadinya disharmoni dan konflik-konflik dalam masyarakat, bahkan peraturan perundangan itu berpotensi untuk tidak dapat berlaku efektif karena tidak dipatuhi oleh warga masyarakat.

\section{Faktor Penyebab Disharmoni Hukum}

Lahirnya Undang Undang Nomor 1 Tahun 2013 tentang Lembaga Keuangan Mikro tidak terlepas dari latar belakang pembuatannya. Sebelum keluarnya UndangUndang ini, dengan berlakunya Pasal 16 dan Pasal 46 Undang Undang Nomor 7 Tahun 1992 tentang Perbankan sebagaimana telah diubah dengan Undang Undang Nomor 10 Tahun 1998 tentang Perubahan atas Undang Undang Perbankan, setiap lembaga keuangan, termasuk LKM untuk melakukan penghimpunan dana simpanan masyarakat (PDSM). Syarat untuk dapat melakukan PDSM bagi lembaga keuangan harus memiliki uandang undang tersendiri yang mengaturnya. Ketentuan Pasal 16 itu hanya bersifat melarang LKM melakukan PDSM. Namun, setelah berlakunya Undang Undang Nomor 1 Tahun 2913 tentang Lembaga Keuangan Mikro yang bertujuan melagalisasi LKM untuk melakukan PDSM, maka dengan undang undang itu ruang gerak LKM justru semakin menjadi terbatas. Undang-undang tidak membiarkan lagi adanya LKM informal, sebab setiap LKM wajib memiliki ijin usaha dari oJK dan harus berbadan hukum. Setiap LKM bahkan dilarang melakukan kegiatan usaha jika LKM itu tidak memiliki ijin dari oJK. Jadi bukan hanya kegiatan usahanya yang dibatasi, bahkan keberadaan atau status kelembagaan LKM itu yang wajib formal. Jadi kalau Pasal 16 pada prinsipnya hanya melarang LKM melakukan PDSM, tetapi Undang Undang Nomor 1 Tahun 2013 bahkan melarang adanya semua jenis LKM yang informal. Negara hendak mengatur seluruh kegiatan usaha LKM yang pada umumnya sederhana dan informal itu dengan pengaturan dan pengawasan secara prudent layaknya lembaga kuangan formal perbankan. Kerangkan hukum yang diterapkan dalam pengaturan LKM tersebut mencerminkan betapa pendekatan legisme hukum nampak dominan menguasasi alam berpikir para penyelenggara negara.

Adapun Faktor-faktor yang menyebabkan ketidak-harmonisan pengaturan hukum LKM Koperasi tersebut antara lain: Pertama, adanya perbedaan dua kepentingan yang kontras, yaitu antara kepentingan untuk penumbuhan dan melindungi kewirausahaan koperasi dengan kepentingan untuk pengaturan dan pengawasan yang ketat lembaga kuangan. Kedua, adanya perbedaan asas/ prinsip antara sistem perkoperasian yang mandiri atau otonom, dengan penerapan prinsip kehati-hatian (prudential principles) yang bersifat mengatur dan memaksa. Antara kedua prinsip bersifat saling bertolak- 
belakang, sehingga pemaksaan untuk menggunakan salah satu prinsip akan mengorbankan prinsip lainnya. Ketiga, adanya pluralitas LKM yang beraneka-ragam tidaklah cocok dengan model pengaturan yang berbasis bentuk kelembagaan. Persoalan utamanya terletak pada kemampuan yang berbeda-beda dari berbagai macam LKM dalam menjalankan fungsi usaha keuangannya. Keempat, adanya kesulitan menemukan titik-temu, kesepakatan, dan koordinasi antar instansi sehingga sikap dan kebijakan antara keduanya inkonsistensi dan bertolak belakang. Kelima, cara pembentukan peraturan perundang-undangan tentang LKM kurang menerapkan principles of legality, serta asas pembentukan perundangundangan yang baik (Fuller, 1971: 39-91).

Menurut Soetandyo Wignjosoebroto, hukum positif yang telah terwujud dalam bentuk undang-undang namun tidak sesuai dengan hukum rakyat berkemungkin tidak akan dipilih warga masyarakat sebagai petunjuk peri1akunya (Soetandyo, 2008: 21). Demikianlah apa yang tengah terjadi dengan Undang Undang Nomor 1 Tahun 2013 yang mengatur tentang pengelolaan dana masyarakat mikro, yang mengandung substansi hukum yang berbeda dengan kebutuhan dan aspirasi sebagian rakyat yang terwujud dalam bentuk praktek pelaksanaan atau kelaziman lembaga keuangan mikro.

Meskipun ditopang oleh sanksi-sanksi yang dilaksanakan secara terorganisasi oleh sejumlah aparat negara, namun hukum produk legislatif ini seringkali tidak efektif dan gagal memperoleh signifikansi sosialnya. Hal itu disebabkan oleh kenyataan bahwa pada umumnya hukum undang undang dipandang kurang sesuai dengan rasa keadilan untuk memperoleh kesempatan yang sama dalam memanfaatkan peluang usaha sesuai dengan kapasitas mereka dan kebutuhan lingkungan setempat, sehingga kepatuhan terhadap hukum yang berpola perbankan itu dipandang kurang menguntungkan kepentingan masyarakat mikro.

Menurut Soetandyo, pengabaian dan penolakan itu akan semakin nyata apabila hukum negara ini ternyata hanya hendak memperbanyak jumlah kewajiban yang harus dipenuhi warga negara dan bukan hendak memberikan hak-hak baru yang akan menjamin warga untuk memperoleh layanan sosial yang memadai dari para pejabat negara (Soetandyo, 2008: 21).
Menghadapi kenyataan seperti itu, hukum undang-undang seakan-akan kehilangan legitimasinya dan kehilangan daya keefektifan serta kebermaknaan sosiologisnya (Soetandyo, 2008: 22). Persoalan yang paling mendasar adalah bahwa para "pelanggar" itu berkilah dengan merujuk ke dasar pembenar yang berada di ranah kesadaran dan keyakinannya sendiri. Itulah keyakinan hukum yang berakar kuat dalam struktur budaya warga masyarakat yang bisa sangat berbeda dengan postulat yang diambil sebagai premis kebijakan negara, baik kebijakan yang terproses di badan-badan legislatif maupun yang diimplementasi di badan-badan eksekutifnya.

Menghadapi kenyataan seperti itu, pemerintah yang tetap mencita-citakan terwujudnya satu sistem hukum yang tunggal (monist), yaitu hukum yang akan berlaku sebagai satu-satunya rujukan normatif untuk perilaku hukum seluruh masyarakat akan selalu berusaha mempersempit (kalaupun tidak sanggup meniadakan) kesenjangan itu.

Kesenjangan hukum (legal gap) itu bukanlah merupakan fakta biasa, sebab the formal legal order dan the popular social order menurut kebijakan para penguasa negara sudah tidak sekadar dipandang sebagai dua yurisdiksi yang masing-masing diakui mempunyai ruang eksistensi sendiri secara terpisah. oleh karena itu, timbullah adanya benturan-beturan kepentingan yang mencerminkan adanya kesenjangan tersebut.

Untuk mewujudkan hormonisasi atas dualisme peraturan hukum bagi LKM Koperasi, peneliti menyarankan agar kerangka hukum yang dibangun untuk mengatur LKM yang pluralistis itu didekati dengan sudut pandang "kesadaran pluralitas" (plurality conscious), dengan menggunakan pendekatan dan teori Triangular Concept of Legal Pluralism dari Werner Menski (Menski, 2006: 173). Teori ini merupakan pendekatan yang bersifat kombinasi atau paduan yang serentak antara pemberlakuan hukum Negara (posited statemade legal rules), hukum masyarakat (social norms), dan hukum etika-moral (ethical values).

Pendekatan pluralisme hukum itu diterapkan agar dimungkinkan untuk melayani kebutuhan hukum secara tepat sesuai dengan keadaan masing-masing lembaga keuangan. Pendekatan pluralisme hukum ini merupakan suatu pendekatan perpaduan untuk dapat berlakunya hukum secara bersama-sama 
antara the formal legal order dengan the popular social order secara serempak.

Pendekatan ini dijadikan kerangka dasar dalam melakukan harmonisasi hukum sehingga langkah sinkronisasi yang akan dilakukan terhadap dualisme peraturan hukum mengenai LKM Koperasi dapat terwujud secara terpadu dan harmonis.

\section{Upaya Harmonisasi dan Sikronisasi}

Langkah dan kebijakan Pemerintah untuk mengarahkan dan mefasilitasi agar LKM menggunakan legalitas kelembagaan dan kegiatan usaha yang prudent layaknya sebuah bank sebenarnya sudah pernah ditempuh oleh Pemerintah melalui penerbitan Peraturan Pemerintah Nomor 71 Tahun 1992 tentang Bank Perkreditan Rakyat (BPR). Di dalam Pasal 19 Peraturan Pemerintah tersebut Pemerintah sudah mengambil langkah agar LKM, termasuk di dalamnya Koperasi, yang belum memiliki legalitas usaha menghimpuan dana simpanan masyarakat (PDSM) diarahkan agar menjadi bank mikro dan difasilitasi dengan mengeluarkan landasan hukum berupa Peraturan Pemerintah tersebut. Namun demikian pada kenyataannya LKM banyak yang tidak melakukan transformasi menjadi bank mikro karena konsekuensinya akan diatur dan diawasi oJK (saat itu BI) yang bersifat prudent. Hal itu menunjukkan bahwa model pengaturan perbankan yang prudent kurang diminati oleh LKM. Adapun lembaga keuangan yang cocok dan siap diatur dan diawasi oleh oJK pad umumnya hanya lembaga keuangan yang sejak awal berdirinya memang bertujuan mendirikan lembaga keuangan berbentuk bank, baik bank umum atau bank mikro (BPR).

Selain itu perlu dicermati pula pengalaman dari hasil penelitian yang dilakukan oleh Sumantoro Martowijoyo. Berdasarkan kesimpulan hasil penelitiannya Sumantoro diungkapkan sebagai berikut: (Sumantoro Martowijoyo, 2001:378)

"bahwa dari penelitian terhadap 100 LKP beserta 303 nasabahnya di Jawa Tengah berhasil diuji bahwa pelaksanaan UU Perbankan No. 7/1992 yang mewajibkan Lembaga Kredit Pedesaan (LKP) mengadaptasi sistem BPR, penerapan penilaian tingkat kesehatan berdasarkan kriteria cAMEL (capital adequacy, assets quality, management, earnings, liquidity), kewajiban pelaporan bulanan beserta peraturan-peraturan pelaksanaan, berdampak negatif terhadap kinerja dan kelestarian LKP, karena: Pertama, membawa implikasi perubahan budaya kinerja, perubahan sistem akuntansi, struktur organisasi, dan peningkatan biaya yang sukar diadaptasi oleh sebagian besar LKP. Apabila sistem BPR akan diterapkan sepenuhnya pada BKD, maka diperkirakan $90 \%$ dari seluruh BKD akan mengalami marjin yang negative. Kedua,........ dst. Ketiga, tidak mendorong efektivitas LKP sebagai lembaga pelayanan keuangan bagi masyarakat miskin di pedesaan karena kriteria cAMEL tidak memperhatikan penyediaan sarana dan "pendalaman" akses pelayanan. Pada awal pemberlakuan cAMEL di tahun 1991/1992, jumlah pemimjam BKK menurun $11,6 \%$ jumlah peminjaman baru berkurang $23 \%$, sebaliknya jumlah pinjaman rata-rata naik sebesar $26,8 \%$ "

Pengalaman yang patut diambil sebagai pelajaran bangsa ialah bahwa pemaksaan hukum kepada lembaga-lembaga mikro informal untuk diatur secara prudent membawa implikasi perubahan budaya kinerja, perubahan sistem akuntansi, struktur organisasi, dan peningkatan biaya yang sukar diadaptasi oleh sebagian besar LKP. Apabila sistem BPR akan diterapkan sepenuhnya pada BKD, maka diperkirakan 90\% dari seluruh BKD akan mengalami marjin yang negative.

Berdasarkan pengalaman mengenai kegagalan-kegagalan tersebut di atas, maka pemberlakukan peraturan perundangan yang memaksa LKM diatur dengan model perbankan dengan pengaturan dan pengawasan yang ketat akan berimplikasi pada 2 kemungkinan, yaitu: (1) lumpuhnya banyak LKM atau terhentinya kegiatan usaha mereka, atau (2) tidak dipatuhinya peraturan perundangan tersebut, sehingga peraturan perundangan itu tidak dapat berjalan efektif. Peraturan yang demikian itu akan menjadi masalah bagi LKM Koperasi yang sejak awal pertumbuhannya sampai menjadi besar berkembang dalam sistem pengaturan yang berprinsip kemandirian dan otonom. Apalagi bagi LKM Koperasi kecil jika diperlakukan sama dengan LKM yang besar, yang samua kegiatannya diatur dan diawasi seperti layaknya lembaga perbankan juga.

Berdasarkan uraian-uraian di atas maka dapat dismpulkan bahwa cara pengaturan terhadap lembaga keuangan jika mendasarkan atau menggunakan pendekatan 
kelembagaan akan menimbulkan berbagai kesenjangan hukum. Artinya, jika pengaturan itu didasarkan pada lembaga mana atau lembaga berbentuk apa yang berwenang melakukan usaha keuangan dan lembaga mana yang dilarang, aturan itu berpotensi menimbulkan ketimpangan-ketimpangan.

Alternatif cara pengaturan lainnya adalah dengan membuat regulasi yang menggunakan pendekatan fungsi dari lembaga keuangan itu. Jika lembaga keuangan tertentu telah mampu menjalankan fungsinya untuk meraih pasar pada skala tertentu, misal diukur dari jumlah peminjam atau penabung, maka lembaga keuangan itu diklassifikasikan sebagai lembaga keuangan yang memiliki hak, kewajiban, larangan, serta ketentuan-ketentuan lainnya yang diatur dengan cara pengaturan sesuai dengan tingkat kemampuan dalam menjalankan fungsinya tersebut. Tingkat kemampuan yang berbeda akan diperlakukan dengan ketentuan yang berbeda pula berdasarkan tingkat kamampuan lembaga dalam menjalankan fungsinya. cara pengaturan yang demikian tidak lagi mendasarkan pada jenis dan bentuk lembaga keuangan apa yang akan diatur, apa pun jenis dan bentuk lembaganya akan diatur menurut fungsi dan kapasitasnya. Jadi lembaga keuangan tertentu, misalnya LKM Koperasi akan dikenakan aturan yang prudent atau non-prudent tergantung pada fungsi atau kemampuannya. Boleh jadi LKM Koperasi tertentu sudah masuk kategori wajib menggunakan aturan prudent, sedangkan LKM Koperasi lainnya masih dikenakan aturan yang bersifat non-prudential. Semua lembaga keuangan itu, baik yang sudah berskala prudent maupun masih non-prudent sama-sama dibiarkan tumbuh dan semua adalah legal. Lembaga keuangan itu baru disebut ilegal jika seharusnya sudah saatnya diatur secara prudent atau bahkan saatnya wajib transformasi ke bentuk bank, tetapi sengaja tidak meningkatkan statusnya.

Pemerintah sebenarnya sudah melakukan pembedaan macam-macam badan usaha dengan menggunakan klasifikasi berdasarkan fungsi dan kapasitas usahanya. Hal itu dapat dilihat pada Undang Undang Nomor 20 Tahun 2008 tentang Usaha Mikro Kecil dan Menengah, yang membuat klasifikasi macam-macam kegiatan usaha itu menjadi Usaha Mikro, Usaha Kecil, dan Usaha Menengah, dengan kriteria yang telah dirumuskan oleh undang undang tersebut. (lihat Pasal 6 UU No.20/ 2008)
Klasifikasi dengan cara yang demikian itu sebenarnya dapat diterapkan dalam peraturan perundangan tentang LKM, sehingga dapat dijadikan patokan bagi oJK, untuk menentukan kepada LKM mana dan kapan oJK harus bertindak untuk pengaturan, pengawasan dan pembinaan terhadap LKM, serta kapan oJK tidak melakukan tindakan tersebut. oleh karena pendekatan pengaturannya berdasarkan fungsi keuangan, bukan berdasarkan bentuk kelembagaan, maka lembaga keuangan bentuk apa saja diberikan kebebasan untuk melakukan usaha keuangan, sedangkan pengaturannya untuk tiap lembaga yang melakukan kegiatan usaha keuangan itu akan disesuaikan dengan tingkat kemampuannya (skalanya) dalam menjalankan fungsi keuangan tersebut.

Dualisme pengaturan terhadap LKM Koperasi telah menimbulkan disharmoni, tumpang-tindih, inkonsistensi, dan kontradiksikontradiksi yang memerlukan pemecahan agar terjadi keselarasan dan memberikan kepastian hukum. Untuk melakukan harmonisasi peraturan-peraturan perundangan tersebut sangat penting dipahami keaneka-ragaman LKM yang diatur, agar masing-masing mendapat pengaturan dan perlakuan secara tepat dan selaras. Oleh sebab itu model pengaturan dengan pendekatan pluralisme hukum kiranya sangat relevan untuk dijadikan alternatif solusi guna mengatur berbagai ragam LKM tersebut. Teori triangular concept of legal pluralism dari Werner Menski telah memberikan pelajaran dan inspirasi berharga untuk memahami keaneka-ragaman LKM, yaitu bahwa setiap entitas hukum lembaga keuangan memiliki karakter dan ciri khas yang perlu diberikan pengaturan sesuai dengan karakternya. Keanekaragaman LKM itu akan dapat berjalan secara sinergis dan saling melengkapi kekurangan LKM yang satu terhadap lainnya dengan pendekatan pluralisme hukum, sebab semua entitas hukum tersebut diberikan ruang gerak untuk menjalankan kegiatan usahanya sesuai dengan karakter dan kapasitasnya masingmasing. Konsekuensinya, pengaturan hukum yang berlaku untuk mereka juga bersifat plural, tidak bersifat monist atau seragam, karena menyediakan beragam saluran.

Melalui pendekatan pluralisme hukum itu maka agar terwujud kesesuaian dan keselarasan antara pengaturan yang prudential dan non-prudential, antara LKM Koperasi yang kecil dengan yang besar diperlakukan secara 
berbeda dalam pengaturannya, meskipun perbedaan itu sangat kontras dan bertolakbelakang. Misalnya bagi LKM Koperasi besar diatur secara prudent dan sudah saatnya untuk dilepaskan dari prinsip otonomi dan kemandirian koperasi, sedangkan bagi LKM Koperasi kecil tetap diperlakukan secara nonprundential serta masih diberikan otonomi sebagaimana cara pengaturan di dalam peraturan perundangan perkoperasian. cara pengaturan yang demikian merupakan model pendekatan kombinatif dalam pengaturan untuk memberlakukan aneka-ragam hukum secara serentak dan terpadu antara diberlakukannya hukum yang otonom dan tidak otonom, formal dan informal, peraturan prudential dan non-prudential bagi beragam entitas LKM Koperasi. Model pengaturan yang bersifat kombinatif ini diterapkan untuk mengatasi dikhotomi dan pertentangan antara hukum negara dan hukum masyarakat, hukum formal dan informal, dan sebagainya. Masing-masing entitas hukum dilindungi dan diperlakukan secara proporsional dan adil sesuai dengan corak hukumnya masingmasing.

Apa yang diuraikan di atas telah menjelaskan bahwa untuk mengatasi problem hukum LKM Koperasi yang tumpang-tindih, inkonsisten dan kontradiktif, diperlukan adanya perubahan pendekatan dan model pengaturannya, yaitu: pertama, pengaturan terhadap LKM Koperasi yang beraneka ragam (plural) itu akan lebih relevan jika diatur dengan pendekatan pluralisme hukum. Kedua, model pengaturan terhadap LKM yang kedaan dan kapastasnya beranekaragam itu akan lebih cocok dan relevan jika diatur dengan mendasarkan pada fungsi atau kapasitas keuangannya, dan bukan mendasarkan pada bentuk lemebagaannya seperti model pengaturan yang diterapkan saat ini.

Jika pemikiran ini dapat diterima, maka alternatif solusi untuk mengatasi tumpangtindih kewenangan, inkonsistensi cara pengaturan, dan kontradiksi antar norma yang mengatur LKM Koperasi dapat diatasi melalui 2 (dua) tahapan. Pertama, sebelum dilakukan sinkronisasi terhadap peraturan perundangan yang terkait, terlebih dahulu perlu dilakukan konseptualisasi untuk mencapai harmonisasiharmonisasi. Langkah-langkah harmonisasi memerlukan adanya perubahan landasan kerangka pengaturan, baik perubahan segi pendekatannya, maupun perubahan segi materi muatan yang terdapat dalam peraturan perundangan yang terkait. Adapun langkah-langkah harmonisasi itu adalah sebagai berikut: (1) menerapkan pendekatan pluralisme hukum untuk mengatur keanekaragam LKM dengan mengacu pada teori trangular concept of legal pluralism dari Werner Menski, (2) mengatur LKM berdasarkan skala/ kapasitas usahanya (pendekatan fungsi), bukan berdasarkan bentuk lembaganya (pendekatan kelembagaan), (3) melakukan rekonstruksi (penataan ulang) hukum yang mengatur tentang lembaga-lembaga keuangan, baik skala kecil maupun besar, melalui pembentukan undang undang baru yang mengatur secara khusus tentang Usaha Keuangan. Undang undang baru ini menggunakan model pengaturan yang bersifat kombinatif yaitu pengaturan yang bersifat prodent dan pengaturan non-prudent secara sekaligus terhadap semua LKM Koperasi yang memiliki aneka skala usaha yang bersifat plural.

Tahap kedua, melakukan sinkronisasi peraturan perundang-undangan yang mengatur tentang LKM Koperasi, yaitu dengan melakukan perubahan dan penambahan ketentuan baru dalam peraturan-peraturan perundangan yang terkait untuk diselaraskan antara satu dengan lainnya, yaitu: (a) Penambahan ketentuan-ketentuan baru di dalam Undang Undang Nomor 1 Tahun 2013 tentang Lembaga Keuangan Mikro, berupa Pasal yang mengatur adanya klasifikasi LKM yang meliputi LKM-Mikro, LKM-Kecil, LKMMenengah, dan LKM-Besar, Penambahan ketentuan ini sekaligus untuk menyelaraskan dengan ketentuan dalam Undang Undang Nomor 20 Tahun 2008 Tentang Usaha Mikro Kecil dan Menengah (UMKM), (b) Menambah ketentuan baru yaitu bagi LKM-Mikro dan LKM-Kecil masih diberikan otonomi untuk mengatur diri dan belum diberlakukan pengaturan yang prudent oleh OJK, sedangkan bagi LKM-Menengah dan LKM-Besar sudah dilepaskan otonominya dan berlaku pengaturan yang bersifat prudent dibawah pengawasan dan pembinaan oJK, atau bagi LKM-Besar diwajibkan untuk trnasformasi ke bentuk bank. Di sini terdapat model pengaturan yang kombinatif menggunakan pendekatan pluralisme hukum, (c) Undang Undang Nomor 1 Tahun 2013 tentang Lembaga Keuangan Mikro perlu lebih memperjelas dan mempertegas ketentuannya tentang hak menghimpun dana simpanan 
masyarakat (PDSM) bagi LKM Koperasi, (d) Undang Undang Nomor 25 Tahun 1992 tentang Perkoperasian juga membuat klasifikasi Koperasi Mikro, Koperasi Kecil, dan Koperasi Menengah, dan Koperasi Besar, serta membuat pembatasan otonomi dan kemandirian Koperasi, untuk mewajibkan bagi yang LKM Koperasi-Menengah dan LKM Koperasi-Besar untuk mengajukan ijin usaha ke oJK atau mewajibkan transformasi ke bentuk bank, (e) Kewenangan pembinaan, pengaturan dan pengawasan bagi LKMMikro dan LKM-Kecil tetap berada di tangan Kementerian Koperasi dan UKM, sedangkan kewenangan pengaturan, pengawasan dan pembinaan bagi LKM Koperasi Menengah dan Besar dilimpahkan kepada OJK, (f) Hukum perkoperasian tetap berlaku penuh bagi LKM Koperasi mikro dan kecil, yaitu berdasarkan prinsip kemandirian dan otonomi Koperasi, dan tetap berada di bawah pembinaan sepenuhnya dari Kementerian Koperasi dan UKM.

\section{Penutup}

1. Hasil penelitian ini menyimpulkan bahwa dualisme hukum yang berlaku bagi LKM Koperasi telah menyebabkan terjadinya keadaan: (1) tumpang-tindih kewenangan dalam hal pengaturan, pengawasan dan pembinaan terhadap LKM Koperasi antara Kementerian Koperasi dan UKM dengan lembaga otoritas Jasa Keuangan/OJK;
(2) Adanya kontradiksi cara pengaturan, di satu sisi perturan hukum perkoperasian memberikan otonomi dan kemandirian bagi Koperasi untuk mengatur-diri dan mengawasi diri sendiri, tanpa campur-tangan dari Pemerintah, namun sebaliknya di dalam peraturan hukum LKM dibuat pengaturan yang prudent dan memberi pengawasan ketat terhadap KLM Koperasi.

2. Faktor-faktor penyebab disharmoni hukum yang mengatur tentang LKM Koperasi adalah: (a) adanya perbedaan prinsip dan kepentingan dalam pengaturan, UU Koperasi mendorong dan melindungi masyarakat agar usaha mikro giat berwirausaha, sedangkan UU LKM ingin mengendalikan dan membatasi kegiatan usaha keuangan untuk meminimalisasi risiko, (b) penggunaan model pengaturan yang hanya berbasis pada bentuk kelembagaan, bukan berbasis pada tingkatan-tingkatan kapasistas usaha LKM, (c) keadaan LKM yang sangat plural, serta (d) kurangnya koordinasi antara instansi terkait.

3. Langkah untuk harmonisasi dan sinkronisasi kedua peraturan hukum LKM Koperasi diatasi melalui 2 (dua) tahapan, yaitu (1) dengan cara melakukan harmonisasi, dan (2) dengan cara melakukan sinkronisasi peraturan hukum terkait dengan LKM Koperasi, yaitu melalu amandemen terhadap Undang Undang Nomor 1 Tahun 2013 tentang Lembaga Keuangan Mikro dan beberapa penambahan ketentuan baru di dalam Undang Undang Nomor 25 Tahun 1992 tentang Perkoperasia. 


\section{daftar Pustaka}

christen, RP, at.al. 2003. Microfinance Consensus Guidelines: Guiding Principles on Regulation and Supervision of Microfinance Institutions, Dipublikasikan oleh: Consultative Group to Assist the Poor (CGAP).

Damien Rousseli re \& Martine V Zina. 2009. Constructing the legitimacy of a financial cooperative in the cultural sector: a case study using textual analysis, International Review of Sociology, Volume $\underline{19}$, Issue $\underline{2}$ July 2009.

Fuller, Lon. L. 1971. Morality of Law, New Haven. conn: Yale University Press,

Menski, Werner. 2006. Comparative Law in a Global Context, The Legal Systems of Asia and Africa, second edition, Cambridge Universuty Press, UK.

Maria Farida Indrati. 2014, Meningkatkan Kualitas Peraturan Perundang-undangan Di Indonesia, http:// tiarramon. wordpress.com/2009/12/16/meningkatkan-kualitas-peraturan-perundang-undangan-diindonesia/ diakses tanggal 3 Nopember 2014

Patrick Meagher. 2002. Microfinance Regulation in Developing Countries: A Comparative Review of Current Practice, IRIS center, University of Maryland.

Peraturan Pemerintah Nomor 9 Tahun 1995 Tentang Pelaksanaan Kegiatan Usaha Simpan Pinjam

Ravik Karsidi. 2014. Peran dan Fungsi Lembaga Keuangan Pedesaan, http://digilib.uns.ac.id/pengguna. php?mn=view\&jen=Makalah, diakses tanggal 11 Nopember 2014

Romli Atmasasmita. 2009. Realitas Hukum, Harian Seputar Indonesia, Selasa 23 Juni 2009

Satjipto Rahardjo. 1996. IImu Hukum, citra Aditya Bakti, Bandung.

Soerjono Soekanto. 1986. Pengantar Penelitian Hukum, UI-Pres, Jakarta.

Soetandyo Wignjosoebroto. 2008. Hukum dalam Masyarakat Perkembangan dan Masalah, cet ke-2, Bayu Media Publishing, Malang,

Sumantoro Martowijoyo. 2001. Dampak Pemberlakuan Sistem Bank Perkreditan Rakyat Terhadap Kinerja Lembaga Pedesaan. Disertasi. S3 Ilmu Ekonomi Universitas Gadjah Mada, Yogyakarta

Undang-Undang Republik Indonesia Nomor 25 Tahun 1992 tentang Perkoperasian

Undang-Undang Republik Indonesia Nomor 1 Tahun 2013 Tentang Lembaga Keuangan Mikro

Keputusan Menteri Keuangan RI No.792 Tahun 1990 tanggal 2 Juni 1990 tentang Lembaga Keuangan

Keputusan Menteri Negara Koperasi dan Usaha Kecil dan Menengah Republik Indonesia Nomor: 91/ Kep/M.KUKM/IX/2004 tanggal 2 Agustus 1994 Tentang Petunjuk Pelaksanaan Kegiatan Usaha Koperasi Jasa Keuangan Syariah. 